\title{
Analysis of Self Efficacy-Sufficiency Levels of Individuals with Visual Impairment According to Some Variables
}

\author{
İbrahim Dalbudak ${ }^{1} \&$ Mihriay Musa ${ }^{2}$ \\ ${ }^{1}$ Atabey Vocational School, Isparta University of Applied Sciences, Isparta, Turkey \\ ${ }^{2}$ Uşak University, Faculty of Sport Sciences, Uşak, Turkey \\ Correspondence: İbrahim Dalbudak, Atabey Vocational School, Isparta University of Applied Sciences, Isparta, \\ Turkey.
}

Received: May 25, 2019

doi:10.5539/ies.v12n10p75
Accepted: July 11, 2019 Online Published: September 29, 2019

URL: https://doi.org/10.5539/ies.v12n10p75

\begin{abstract}
This study was conducted with the aim of determining self efficacy-sufficiency levels of visually impaired individuals according to some variables. Bandura (1994) states that self-sufficiency, defined as an individual's belief on operating a specific job, is an important factor for the athletes. Self-sufficiency results in choosing a field of study voluntarily, feeling a high motivation for accomplishing that job, endeavoring and spending time on the study. Self-sufficiency is about the individual's specific area or behavior group (Akkoyunlu \& Orhan, 2003). The study was conducted on 127 male and 60 female visually-impaired individuals, a total of 187, with different visual acuity in different visually-handicapped clubs. The voluntary basis was taken into consideration in participation. As the data collection tool, "Personal Information Form" and "Self-Efficacy-Sufficiency Scale" which was developed by Sherer et al. (1982), and adopted into Turkish by Gözüm and Aksayan (1999). The data set was analyzed in SPSS 20.0 packaged programme. The data was purified from loss and wrong coding, and the normality hypothesis was done with kurtosis and skewness values. In the analysis of the data, frequency, the average standard deviation was used; besides, T-Test (in paired comparisons) gender, disability status, marital status and branches of sports; one-way variance (ANOVA) test in age, level of education, level of income and visual acuity were used. When one-way ANOVA results of self-sufficiency scores according to gender, age, disability status, level of education, level of income, and visual acuity were analyzed, it was stated that there was a significant difference $(p<0,05)$, and there is no significant difference in Self-Sufficiency scores of visually-impaired individuals who are doing team and individual sports $(p>0,05)$. When evaluated the information above, it can be said that like self efficacy-sufficiency concept can be in different levels and different dimension in different areas of life; it is effective on visually-impaired individuals. In this respect, it is considered that this study will open a new window to this area and contribute to the visually-impaired athletes. Besides, it is suggested that a new study on how self efficacy-sufficiency concept is in the visually-impaired athletes and other individuals, and evaluation of how they are affected. In this concept, the general aim of this study is to analyze the levels of self efficacy-sufficiency of visually-impaired athletes.
\end{abstract}

Keywords: visually-impaired athlete, self efficacy-sufficiency, behaviour

\section{Introduction}

The concept of Self-Efficacy-Sufficiency was first introduced by the famous psychologist Albert Bandura in 1977 within the context of "Cognitive Behavior Change" (Yiğitbaş \& Yetkin, 2003). The concept of self-sufficiency is the subject of research in many processes related to education such as learning and performance. In other words, it is the belief that it has the capacity to organize and complete the necessary activities in order to perform a certain performance (Yllmaz, Gürcay, \& Ekici, 2007). Bandura (1986) defined self-efficacy beliefs as judgments about the ability of organizing and presenting actions that enable people to reach a certain performance. Self-sufficiency is the personal belief that an individual can achieve a certain task. Self-sufficiency is a belief. Sufficiency means the degree of having the necessary knowledge, skills and attitudes to play a role, the employee's realizing the expected roles in the expected quantity and quality means having the knowledge and skills to perform a behavior (Üstüner et al., 2009). Self-efficacy; is an important point that determines how a person thinks, how he feels, and how he acts. Low self-sufficiency feeling results in depression and helplessness feeling. Besides, such people have low self-confidence. Self-sufficiency level may prevent or accelerate the instincts. The ones with high 
self-sufficiency can choose harder and riskier jobs. They aim for the sky and they covetously work for reaching it (Schwarzer \& Fuchs, 1995). High self-sufficiency belief causes high desire to succeed, low self-sufficiency belief causes to low desire succeed; on the other hand, it is seen that high desire to succeed causes high self-sufficiency and low desire to succeed causes low self-sufficiency (Chase, 1998). Self-sufficiency is about individual's only one area or behavior group. In other words, for example, the individual has a high self-efficacy belief in any field, for example, second language learning; while in another field he may have developed a low self-efficacy belief in, for example, soccer playing (Akkoyunlu \& Orhan, 2003).

Self-efficacy beliefs, defined as the individual's belief in the capacity to perform a certain job, are an important factor for athletes (Bandura, 1994). As self-efficacy is a strong determinant of the performance and success level of athletes, it is also of great importance for competitions and rivals, which is the most important process for athletes due to the realization of the desired behaviors through the skills acquired (Türedi, 2015). The method of improving individual's self-efficacy perception is to provide physical development, to reduce stress level, to minimize negative emotional tendency, and to correct misinterpretations for body condition (Bandura, 1997). Among athletes with high or low self-efficacy, it can be stated that working discipline and using new methods strongly affect sporting success (Cengiz, Korucu-Aytan, \& Abakay, 2012). Another factor affecting the expectation of sufficiency is the positive and negative turns (messages) that an individual receives from the interaction. For example, when a person is eloquently defended that he has the skills required for the task; self-efficacy expectations may increase (Eysenck, 2000). In this respect, the level of performance of individuals or groups with high self-efficacy belief is high. Individuals with high self-efficacy beliefs set higher goals for themselves, thus their motivation levels increase and perform better (Bandura, 1997; Bray, 2004; Gibson, 1999; Gibson, Randel, \& Early, 2000; Guzzo et al., 1993; Myers et al., 2004; Sbea \& Guzzo, 1987).

There are 1.3 billion visually-impaired people in the world. Among these people, 188.5 million people have mild vision, 217 million have moderate to severe visual impairment, and 36 million are blind (WHO, 2013). According to Turkey Disability Survey (Turkey Disability Survey, 2002), "visually impaired" people constitute 0.60 's\% of the population. Visually-impareid: It is expressed as one or two eyes' loss of ability to see as a whole or in part. Low vision; after the standard refractive corrections, whose visual impairment is continuing and visual acuity is less than 6/18 (20/60), but it is the person who can use it to plan and perform a job (Ak1 and Kayihan, 2003). Visually impaired athletes are divided into B1, B2, B3 according to the IBSA rules. B1 has no visual acuity, individuals with $\mathrm{B} 2$ and $\mathrm{B} 3$ visual acuity have low sight.

The visually impaired individuals, by means of sports and education, can accept the obstacle of sight, and in this life, we can say that they have increased their strong belief, continuity and effort. The high level of self-sufficiency may be shown as a proof of success in sports. In education; We can say that self-sufficiency is important for her to continue her education, for how much effort she will undertake and how much continuity she has achieved in this endeavor.

Considering the information above; it can be said that the concept of self-efficacy-sufficiency can be effective on different dimensions and levels of life in different areas of life and it may be effective on visually impaired individuals. In this respect, it is thought that this study will contribute to the visually impaired athletes and will bring a different perspective to this field. In this context, the general aim of the study is to examine the self efficacy-sufficiency level of the visually impaired athletes according to some variables.

In this study, self-efficacy-sufficiency concept was performed with 187 visually impaired athletes with different visual impairments. The principle of voluntary basis was taken into consideration. In this context, the problems of this study are:

- What is self efficacy-sufficiency level of the visually-impaired athletes according to their gender?

- What is self efficacy-sufficiency level of the visually-impaired athletes according to their disability status?

- What is self efficacy-sufficiency level of the visually-impaired athletes according to their branches of sports?

- What is self efficacy-sufficiency level of the visually-impaired athletes according to their age groups?

- What is self efficacy-sufficiency level of the visually-impaired athletes according to their education status?

- What is self efficacy-sufficiency level of the visually-impaired athletes according to their level of income?

- What is self efficacy-sufficiency level of the visually-impaired athletes according to their visual acuity?

\section{Materials and Methods}

Study Group: The study group was conducted on 127 male and 60 females visually-impaired individuals, a total of 187 , with different visual acuity in different visually-handicapped clubs. Voluntary basis was taken into 
consideration in participation.

\subsection{Data Collection Tools}

In obtaining the data; "Personal Information Form", which consists of two parts, prepared by the researcher related to demographic characteristics and "Self Efficacy-Sufficiency Scale" are used. In the first part, students' personal information form (age, gender, educational status, sports branch, obstacle situation, the degree of vision, income level) are available.

In the second part, self-efficacy sufficiency scale which was developed by Sherer et al. (1982), and adopted into Turkish by Gözüm and Aksayan (1999) was used and for validity and reliability of the same sample; Cronbach Alpha coefficiency .81, test-re-test reliability was found as .92 The Self-Efficacy-Sufficiency Scale (SESS) is a 5-point Likert-type self-assessment scale. The participants were asked to choose one of the options for each item on a scale of 23 items; 1-doesn't define me at all, 2-“defines me a little", 3-"I'm indecisive", 4-defines me little ", 5-"defines me well". The score given for each item is based on. However, 2, 4, 5, 6, 7, 10, 11, 12, 14, 16, 17, 18, 20, 22 items are scored in the opposite direction. Thus, at least 23, maximum of 115 points can be taken from the scale. The high total score obtained from the scale indicates that the individual's perception of is SES at a good level. The scale has four sub-factors. These are; 1) Starting behavior: 2, 11, 12, 14, 17, 18, 20, 22. 2) Maintaining the behavior: 4, 5, 6, 7, 10, 16, 19. 3) Behavior completion: 3, 8, 9, 15, 23. 4) Struggle against obstacles: 1, 13, 21. (Gözüm \& Aksayan, 1999). The total Cronbach Alpha value of the scale was 0.690.

\subsection{Analysis of the Data}

Before assuming data analysis, analysis assumptions were examined. The data from the lost and incorrect codings were purged and the normality assumption was tested with the skewness and kurtosis values. Then, in the analysis of the data, frequency, the average standard deviation is used; One-way variance (ANOVA) test was used for the analysis according to gender, disability, marital status and branches of sports.

In variance analysis, the Bonferroni method is widely used multiple comparison tests and does not require the principle of the equal number of samples (Miller, 1969; cited in Kayri, 2009). Therefore, in the case of significant differences, the variance analysis results were compared using the Bonferroni test. The analyzes were tested with SPSS 22.00 at .05 significance level.

Within the concept of normality tests, table 1 presents descriptive statistics on participants' self-efficacy scores. It is seen that the kurtosis and skewness values of the variable are 1.325 and -1.384 and these values are seen to be between -2 and +2 . George and Mallery (2010) stated that these data are normally distributed at an acceptable rate if the kurtosis and skewness values are between -2 and +2 . Therefore, it can be said that the variable has a normal distribution.

\section{Findings}

Table 1. Descripted statistics on self-sufficiency scores

\begin{tabular}{cccccc}
\hline Variable & $\mathrm{N}$ & Average & Standard Deviation & Kurtosis & Skewness \\
\hline Self Sufficiency & 187 & 41.932 & 0.42774 & 1.325 & -1.384 \\
\hline
\end{tabular}

The sample of the study was conducted on visually-impaired individuals with different visual acuity in different visually-handicapped clubs. A total of 187 individuals with different visual acuity in different visually-handicapped clubs voluntarily participated in the study. In this part of the study, the scores that athletes got and their answers were revealed and interpreted.

Table 2. Visually-impaired individuals' distribution according to their age, disability status, gender, education status, branches of sports, level of income, and visual acuity

\begin{tabular}{lccc}
\hline & & $\mathrm{n}$ & $\%$ \\
\hline \multirow{2}{*}{ Gender } & Male & 127 & 67,9 \\
& Female & 60 & 32,1 \\
Age & Under 18 & 38 & 15,6 \\
& $18-30$ & 102 & 54,2 \\
Disability Status & $30+$ & 47 & 30,2 \\
& Congenital & 161 & 86,1 \\
\hline
\end{tabular}




\begin{tabular}{lccc}
\hline \multirow{5}{*}{ Education Status } & Afterward & 26 & 13,9 \\
& Primary & 20 & 10,7 \\
& High Schol & 86 & 46 \\
& University & 81 & 43,3 \\
Branches of Sports & Individual S. & 144 & 77 \\
& Team S. & 43 & 23 \\
Level of Income & 1000 & 30 & 16 \\
& $1001-2000$ & 154 & 82,4 \\
Visual Acuity & 3000 & 3 & 1,6 \\
& B1 & 61 & 32,6 \\
& B2 & 74 & 39,6 \\
\hline
\end{tabular}

Table 3 shows the t-test findings for independent samples of participants' self-efficacy scores according to gender.

Table 3. Findings on self-sufficiency scores of the participants according to gender

\begin{tabular}{lccccccc}
\hline & Gender & $\mathrm{N}$ & Average & Std. D. & $\mathrm{t}$ & Std. D. & $\mathrm{P}$ \\
\hline \multirow{2}{*}{ Starting Behavior } & Male & 127 & 93.7156 & 7.54798 & 5.109 & 185 & .000 \\
& Female & 60 & 84.9288 & 16.01182 & & & .000 \\
Maintaining the Behavior & Male & 127 & 95.5482 & 10.05048 & 5.931 & 185 & .014 \\
& Female & 60 & 84.5438 & 14.97452 & & & \\
Completion of the Behavior & Male & 127 & 100.7842 & 7.86764 & 2.490 & 185 & .014 \\
& Female & 60 & 96.2126 & 17.27 & & & .066 \\
Struggle Against Obstacles & Male & 127 & 86.4996 & 18.8518 & 1.850 & 185 & .000 \\
& Female & 60 & 80.6674 & 22.59268 & & & \\
Average & Male & 127 & 94.8684 & 5.03624 & 6.041 & 185 & .000 \\
\hline
\end{tabular}

When findings on self-sufficiency scores of the participants according to gender are analyzed, it is stated that there is a significant difference in participants' scores, and males have higher self-sufficiency scores than the females $(\mathrm{t}$ $(185)=6,041, p<.05)$. When looked at the sub-factors of self-efficacy scores; there is a significant difference in favor of the males according to gender in sub-factors of Starting Behavior $(\mathrm{t}(185)=5,109, \mathrm{p}<.05)$, Maintaining Behavior ( $\mathrm{t}(185)=5,931, \mathrm{p}<.05)$, Completion of the Behavior $(\mathrm{t}(185)=2,490, \mathrm{p}<.05)$; in Struggle against Obstacles sub-scale ( $(185)=1,850, p>.05)$, it was determined that there was no significant difference according to gender.

Table 4 shows the t-test findings for independent samples of participants' attitudes towards self-sufficiency according to their disability status.

Table 4. Findings on self-sufficiency scores of the participants according to disability status

\begin{tabular}{llcccccc}
\hline & $\begin{array}{c}\text { Disability } \\
\text { Status }\end{array}$ & $\mathrm{N}$ & Average & Std D. & $\mathrm{t}$ & Std. D. & $\mathrm{p}$ \\
\hline \multirow{2}{*}{ Starting Behavior } & Congenital & 161 & 90.3738 & 12.07536 & -1.526 & 185 & .129 \\
& Afterward & 26 & 94.1336 & 8.49596 & & & \\
Maintaining Behavior & Congenital & 161 & 90.9282 & 13.30208 & -2.933 & 185 & .004 \\
& Afterward & 26 & 98.758 & 6.95266 & & & \\
Completion of the Behavior & Congenital & 161 & 98.5754 & 12.28238 & -2.144 & 185 & .033 \\
& Afterward & 26 & 103.9082 & 7.67932 & & & .763 \\
Struggle Against Obstacles & Congenital & 161 & 84.447 & 20.93696 & -.302 & 185 & .763 \\
& Afterward & 26 & 85.7428 & 15.62792 & & & .011 \\
Average & Congenital & 161 & 91.553 & 9.63336 & -2.561 & 185 & \\
\hline
\end{tabular}

When findings on self-sufficiency scores of the participants according to disability status are analyzed, it was 
found that there was a significant difference in individuals with congenital and afterward disability $(\mathrm{t}(185)=$ $-2.561, \mathrm{p}<.05$ ). When looked at the sub-factors of self-efficacy scores; there is a significant difference in favor of the individuals with afterward disability in sub-factors of Maintaining Behavior $(\mathrm{t}(185)=-2,933, \mathrm{p}<.05)$, Completion of the Behavior ( $\mathrm{t}(185)=-2,144, \mathrm{p}<.05)$; in Starting Behavior $(\mathrm{t}(185)=-1,526, \mathrm{p}>.05)$ and Struggle Against Obstacles sub-scales $(\mathrm{t}(185)=-.302, \mathrm{p}>.05)$, it was determined that there was no significant difference in individuals with congenital and afterward disability.

Table 5 shows the t-test findings for independent samples of participants' attitudes towards self-sufficiency according to their branches of sports.

Table 5. Findings on self-sufficiency scores of the participants according to branches of sports

\begin{tabular}{lccccccc}
\hline & Branches of Sports & $\mathrm{N}$ & Average & Std. D. & $\mathrm{t}$ & Std. D. & $\mathrm{p}$ \\
\hline \multirow{2}{*}{ Starting Behavior } & Individual S. & 144 & 91.553 & 12.22452 & 1.405 & 185 & .162 \\
& Team S. & 43 & 88.704 & 9.52798 & & \\
Maintaining Behavior & Individual S. & 144 & 91.9292 & 13.25874 & -.171 & 185 & .865 \\
& Team S. & 43 & 92.312 & 11.69982 & & & \\
Completion of the Behavior & Individual S. & 144 & 98.3884 & 12.82666 & -1.972 & 185 & .050 \\
& Team S. & 43 & 102.4276 & 7.2061 & & & \\
Struggle Against Obstacles & Individual S. & 144 & 82.1942 & 20.28114 & -3.074 & 185 & .002 \\
& Team S. & 43 & 92.7762 & 18.09676 & & \multirow{2}{*}{185} & .399 \\
Average & Individual S. & 144 & 91.9314 & 9.78032 & -.846 & 185 \\
& Team S. & 43 & 93.3174 & 8.06058 & & & \\
\hline
\end{tabular}

When findings on self-sufficiency scores of the participants according to branches of sports were analyzed, it was found that there was no significant difference in individuals doing team sports and individual sports $(\mathrm{t}(185)=$ $-.846, \mathrm{p}>.05)$. When looked at the sub-factors of self-efficacy scores; there was no significant difference in sub-factors of Starting Behavior ( $\mathrm{t}(185)=1.405, \mathrm{p}>.05)$, Maintaining Behavior $(\mathrm{t}(185)=-.171, \mathrm{p}>.05)$ and Completion of the Behavior ( $\mathrm{t}(185)=-1.972, \mathrm{p}>.05$ ) according to branches of sports; in Struggle Against Obstacles sub-scales $(\mathrm{t}(185)=-3.074, \mathrm{p}<.05)$, it was determined that there was a significant difference in favor of individuals doing team sports.

Table 6 shows the one-way ANOVA findings for independent samples of participants' attitudes towards self-sufficiency according to their age groups.

Table 6. Findings on self-sufficiency scores of the participants according to age groups

\begin{tabular}{|c|c|c|c|c|c|c|}
\hline & & Sum of Squares & Std. D. & Average of Squares & $\mathrm{F}$ & $\mathrm{P}$ \\
\hline \multirow{3}{*}{ Starting Behavior } & Inter-Groups & 5.253 & 2 & 2.626 & 10.209 & .000 \\
\hline & Intra-Group & 47.333 & 184 & .257 & & \\
\hline & Total & 52.585 & 186 & & & \\
\hline \multirow{3}{*}{ Maintaining Behavior } & Inter-Groups & 5.702 & 2 & 2.851 & 9.025 & .000 \\
\hline & Intra-Group & 58.125 & 184 & .316 & & \\
\hline & Total & 63.827 & 186 & & & \\
\hline \multirow{3}{*}{$\begin{array}{l}\text { Completion of the } \\
\text { Behavior }\end{array}$} & Inter-Groups & 1.398 & 2 & .699 & 2.435 & .090 \\
\hline & Intra-Group & 52.833 & 184 & .287 & & \\
\hline & Total & 54.231 & 186 & & & \\
\hline \multirow{3}{*}{$\begin{array}{c}\text { Struggle Against } \\
\text { Obstacles }\end{array}$} & Inter-Groups & 10.147 & 2 & 5.073 & 6.330 & .002 \\
\hline & Intra-Group & 147.459 & 184 & .801 & & \\
\hline & Total & 157.605 & 186 & & & \\
\hline \multirow{3}{*}{ Average } & Inter-Groups & 2.831 & 2 & 1.415 & 8.348 & .000 \\
\hline & Intra-Group & 31.200 & 184 & .170 & & \\
\hline & Total & 34.031 & 186 & & & \\
\hline
\end{tabular}

When one-way ANOVA results related to Self-Sufficiency scores according to age groups were examined, it was determined that there was a significant differentiation of Self-Sufficiency scores of the participants in terms of age groups $(\mathrm{F}(2,184)=8.348, \mathrm{p}<.05)$. When sub-factors were analyzed according to age groups, it was found that 
there was differentiation in sub-factors of Starting Behavior $(\mathrm{F}(2,184)=10.209, \mathrm{p}<.05)$, Maintaining Behavior $(\mathrm{F}(2,184)=9.025, \mathrm{p}<.05)$ and Struggle Against Obstacles $(\mathrm{F}(2,184)=6.330, \mathrm{p}<.05)$; but in sub-factor of Completion of the Behavior $(2,184)=2.435, \mathrm{p}>.05)$, it was determined that there was no significant difference according to age groups. As a result of Post Hoc tests to determine in which of these three sub-factors the differentiation occurred; it was stated that there was difference between under 18 years and 18-30 years, under 18 years and over 30 years in Starting Behavior; under 18 years and 18-30 years, and 18-30 years and over 30 years in Maintaining Behavior; under 18 years and over 30 years in Struggle against Obstacles. In terms of self-efficacy scores, it was determined that there were differences between the ages of under 18 and 18-30, under 18 years and over 30 years.

One-way analysis of variance (ANOVA) results for the Self-Efficacy scores according to the education status of the participants is given in Table 7.

Table 7. Findings on self-sufficiency scores of the participants according to education status

\begin{tabular}{|c|c|c|c|c|c|c|}
\hline & & $\begin{array}{l}\text { Sum of } \\
\text { Squares } \\
\end{array}$ & Std. D. & $\begin{array}{c}\text { Average of } \\
\text { Squares }\end{array}$ & $\mathrm{F}$ & $\mathrm{P}$ \\
\hline \multirow{3}{*}{ Starting Behavior } & Inter-Groups & 6.132 & 2 & 3.066 & 12.145 & .000 \\
\hline & Intra-Group & 46.453 & 184 & .252 & & \\
\hline & Total & 52.585 & 186 & & & \\
\hline \multirow{3}{*}{$\begin{array}{l}\text { Maintaining } \\
\text { Behavior }\end{array}$} & Inter-Groups & 4.584 & 2 & 2.292 & 7.118 & .001 \\
\hline & Intra-Group & 59.244 & 184 & .322 & & \\
\hline & Total & 63.827 & 186 & & & \\
\hline \multirow{3}{*}{$\begin{array}{l}\text { Completion of the } \\
\text { Behavior }\end{array}$} & Inter-Groups & .784 & 2 & .392 & 1.349 & .262 \\
\hline & Intra-Group & 53.447 & 184 & .290 & & \\
\hline & Total & 54.231 & 186 & & & \\
\hline \multirow{3}{*}{$\begin{array}{c}\text { Struggle Against } \\
\text { Obstacles }\end{array}$} & Inter-Groups & 22.518 & 2 & 11.259 & 15.336 & .000 \\
\hline & Intra-Group & 135.087 & 184 & .734 & & \\
\hline & Total & 157.605 & 186 & & & \\
\hline \multirow{3}{*}{ Average } & Inter-Groups & 4.676 & 2 & 2.338 & 14.655 & .000 \\
\hline & Intra-Group & 29.355 & 184 & .160 & & \\
\hline & Total & 34.031 & 186 & & & \\
\hline
\end{tabular}

When one-way ANOVA results related to Self-Sufficiency scores according to education status were examined, it was found that there was a differentiation in self-sufficiency scores of the participants according to education status $(\mathrm{F}(2,184)=14.655, \mathrm{p}<.05)$. When sub-factors were analyzed according to education status; it was found that there was difference in sub-factors of Starting Behavior $(2,184)=12.145, \mathrm{p}<.05)$, Maintaining Behavior (F $(2,184)=7.118, p<.05)$, and Struggle against Obstacles $(F(2,184)=15.336, p<.05)$; but in Completion of the Behavior $(\mathrm{F}(2,184)=1.349, \mathrm{p}>.05)$, it was found that there was no difference. As a result of Post Hoc tests to determine in which of these three sub-factors the differentiation occurred; it was stated that there was difference; it was found that there was difference among all groups in Starting Behavior scores; between primary school and high school graduates, and primary school and university graduates in Maintaining the Behavior; between primary school and university graduates, and high school and university graduates in Struggle against Obstacles. In general average, it was found that there was significant differentiation among groups.

One-way analysis of variance (ANOVA) results for the Self-Efficacy scores according to the level of income of the participants is given in Table 8 .

Table 8. Findings on self-sufficiency scores of the participants according to level of income

\begin{tabular}{ccccccc}
\hline & & Sum of & Std. D. & $\begin{array}{c}\text { Average of } \\
\text { Squares }\end{array}$ & F & P \\
\hline \multirow{3}{*}{ Starting Behavior } & Inter-Groups & 8.212 & 2 & 4.106 & 17.026 & .000 \\
& Intra-Group & 44.374 & 184 & .241 & & \\
Maintaining & Total & 52.585 & 186 & & & \\
Behavior & Inter-Groups & 4.040 & 2 & 2.020 & \multirow{2}{*}{6.217} & .002 \\
\hline
\end{tabular}




\begin{tabular}{|c|c|c|c|c|c|c|}
\hline & Total & 63.827 & 186 & & & \\
\hline & Inter-Groups & 1.367 & 2 & .684 & 2.380 & .095 \\
\hline \multirow[t]{3}{*}{ Completion of the Behavior } & Intra-Group & 52.864 & 184 & .287 & & \\
\hline & Total & 54.231 & 186 & & & \\
\hline & Inter-Groups & 10.083 & 2 & 5.041 & 6.288 & .002 \\
\hline \multirow[t]{3}{*}{ Struggle Against Obstacles } & Intra-Group & 147.523 & 184 & .802 & & \\
\hline & Total & 157.605 & 186 & & & \\
\hline & Inter-Groups & 3.743 & 2 & 1.872 & 11.370 & .000 \\
\hline \multirow[t]{2}{*}{ Average } & Intra-Group & 30.287 & 184 & .165 & & \\
\hline & Total & 34.031 & 186 & & & \\
\hline
\end{tabular}

When one-way ANOVA results related to Self-Sufficiency scores according to level of income were examined, it was found that there was a differentiation in self-sufficiency scores of the participants according to level of income $(\mathrm{F}(2,184)=11.370, \mathrm{p}<.05)$. When sub-factors were analyzed according to level of income; it was found that there was difference in sub-factors of Starting Behavior $(2,184)=17.026, \mathrm{p}<.05)$, Maintaining Behavior $(\mathrm{F}(2$, $184)=6.217, \mathrm{p}<.05)$, and Struggle against Obstacles $(\mathrm{F}(2,184)=6.288, \mathrm{p}<.05)$; but in sub-factor of Completion of the Behavior $(\mathrm{F}(2,184)=2.380, \mathrm{p}>.05)$, it was found that there was no differentiation. As a result of Post Hoc tests to determine in which of these three sub-factors the differentiation occurred; it was stated that there was difference between 1000 and 3000, and 1001-2000 and 3000 in general average of the self-sufficiency. In sub-factors; it was found that there was significant difference in Starting Behavior scores between 1000 and 3000, ad 1001-2000 and 3000; between 1000 and 3000, and 1001-2000 and 3000 in Maintaining Behavior score; between 1000 and 3000, and 1001-2000 and 3000 in Struggle against Obstacles.

One-way analysis of variance (ANOVA) results for the Self-Efficacy scores according to the visual acuity of the participants is given in Table 9.

Table 9. Findings on self-sufficiency scores of the participants according to visual acuity

\begin{tabular}{|c|c|c|c|c|c|c|}
\hline & & Sum of Squares & Std. D. & Average of Squares & $\mathrm{F}$ & $\mathrm{P}$ \\
\hline \multirow{3}{*}{ Starting Behavior } & Inter-Groups & 2.670 & 2 & 1.335 & 4.922 & .008 \\
\hline & Intra-Group & 49.915 & 184 & .271 & & \\
\hline & Total & 52.585 & 186 & & & \\
\hline \multirow{3}{*}{$\begin{array}{c}\text { Maintaining } \\
\text { Behavior }\end{array}$} & Inter-Groups & 6.113 & 2 & 3.057 & 9.745 & .000 \\
\hline & Intra-Group & 57.714 & 184 & .314 & & \\
\hline & Total & 63.827 & 186 & & & \\
\hline \multirow{3}{*}{$\begin{array}{c}\text { Completion of the } \\
\text { Behavior }\end{array}$} & Inter-Groups & 3.163 & 2 & 1.582 & 5.699 & .004 \\
\hline & Intra-Group & 51.068 & 184 & .278 & & \\
\hline & Total & 54.231 & 186 & & & \\
\hline \multirow{3}{*}{$\begin{array}{c}\text { Struggle Against } \\
\text { Obstacles }\end{array}$} & Inter-Groups & 1.120 & 2 & .560 & .659 & .519 \\
\hline & Intra-Group & 156.485 & 184 & .850 & & \\
\hline & Total & 157.605 & 186 & & & \\
\hline \multirow{3}{*}{ Average } & Inter-Groups & 2.929 & 2 & 1.465 & 8.665 & .000 \\
\hline & Intra-Group & 31.101 & 184 & .169 & & \\
\hline & Total & 34.031 & 186 & & & \\
\hline
\end{tabular}

When one-way ANOVA results related to Self-Sufficiency scores according to visual acuity were examined, it was found that there was a differentiation in self-sufficiency scores of the participants according to visual acuity ( $\mathrm{F}(2$, $184)=8.665, \mathrm{p}<.05)$.

When sub-factors were analyzed according to visual acuity, it was found that there was difference in sub-factors of Starting Behavior $(2,184)=4.922, \mathrm{p}<.05)$, Maintaining Behavior $(\mathrm{F}(2,184)=9.745, \mathrm{p}<.05)$, and Completion of the Behavior $(\mathrm{F}(2,184)=5.699, \mathrm{p}<.05)$ according to visual acuity; but in sub-factor of Struggle against Obstacles, it was found that there was no difference according to visual acuity.

As a result of Post Hoc tests to determine in which of these three sub-factors the differentiation occurred; it was stated that there was difference between B2 and B3 in Starting Behavior; between B1 and B3, B2 and B3 in Maintaining the Behavior; between B1 and B2, and B2 and B3 in Completion of the Behavior. In general average 
of the Self-Sufficiency, it was found that there was difference between B2 and B3 while there were no differentiations between visual acuity levels.

\subsection{Additional Tables}

Table 10. Average scores of the participants according to their age groups

\begin{tabular}{ccccc}
\hline & & $\mathrm{N}$ & $\mathrm{X}$ & $\mathrm{Std}$. D. \\
\hline \multirow{4}{*}{ Starting Behavior } & Under 18 years & 38 & 98.131 & 8.58044 \\
& $18-30$ years & 102 & 88.6732 & 11.99902 \\
& Over 30 years & 47 & 89.8722 & 11.07612 \\
& Total & 187 & 90.8974 & 11.69762 \\
& Under 18 years & 38 & 97.1806 & 6.55116 \\
Maintaining Behavior & $18-30$ years & 102 & 88.5544 & 14.0789 \\
& Over 30 years & 47 & 95.3546 & 11.9097 \\
& Total & 187 & 92.0172 & 12.8876 \\
Completion of the & Under 18 years & 38 & 102.7048 & 7.74202 \\
Behavior & $18-30$ years & 102 & 99.0858 & 8.59562 \\
& Over 30 years & 47 & 97.0816 & 18.58648 \\
Struggle against & Total & 187 & 99.3168 & 11.87934 \\
Obstacles & Under 18 years & 38 & 88.5786 & 13.1384 \\
& $18-30$ years & 102 & 87.2102 & 22.55946 \\
& Over 30 years & 47 & 75.8296 & 17.1831 \\
& Total & 187 & 84.6274 & 20.25122 \\
Total & Under 18 years & 38 & 97.5898 & 3.65068 \\
& $18-30$ years & 102 & 90.7104 & 9.83048 \\
& Over 30 years & 47 & 91.2758 & 10.26476 \\
& Total & 187 & 92.2504 & 9.41028 \\
\hline
\end{tabular}

Table 11. Average scores of the participants according to their education status

\begin{tabular}{ccccc}
\hline & & $\mathrm{N}$ & $\mathrm{X}$ & $\mathrm{Std}$. D. \\
\hline \multirow{3}{*}{ Starting Behavior } & Primary S. & 20 & 100.1 & 8.19676 \\
& High School & 86 & 92.2526 & 7.47076 \\
& University & 81 & 87.186 & 14.3451 \\
& Total & 187 & 90.8974 & 11.69762 \\
& Primary S. & 20 & 101.8292 & 4.82592 \\
Maintaining Behavior & High School & 86 & 91.4342 & 10.8405 \\
& University & 81 & 90.211 & 15.1008 \\
& Total & 187 & 92.0172 & 12.8876 \\
& Primary S. & 20 & 103.4 & 8.13824 \\
Completion of the Behavior & High School & 86 & 98.6414 & 14.8863 \\
& University & 81 & 99.0264 & 8.49574 \\
& Total & 187 & 99.3168 & 11.87934 \\
& Primary S. & 20 & 96.0674 & 13.22574 \\
& High School & 86 & 89.9602 & 18.66854 \\
& University & 81 & 76.1398 & 20.1355 \\
& Total & 187 & 84.6274 & 20.25122 \\
& Primary S. & 20 & 100.8172 & 1.59456 \\
& Tigh School & 86 & 93.093 & 6.70208 \\
& University & 81 & 89.2408 & 11.3696 \\
& Total & 187 & 92.2504 & 9.41028 \\
\hline
\end{tabular}


Table 12. Average scores of the participants according to their level of income

\begin{tabular}{ccccc}
\hline & & $\mathrm{N}$ & $\mathrm{X}$ & Std. D. \\
\hline \multirow{4}{*}{ Starting Behavior } & 1000 & 30 & 97.075 & 8.14352 \\
& $1001-2000$ & 154 & 90.2858 & 11.30492 \\
& 3000 & 3 & 60.5 & 0 \\
& Total & 187 & 90.8974 & 11.69762 \\
& 1000 & 30 & 93.6562 & 4.47524 \\
Maintaining Behavior & $1001-2000$ & 154 & 92.1844 & 13.61228 \\
& 3000 & 3 & 67.0472 & 1.81456 \\
& Total & 187 & 92.0172 & 12.8876 \\
Completion of the & 1000 & 30 & 102.52 & 6.75246 \\
Behavior & $1001-2000$ & 154 & 98.5138 & 12.58972 \\
& 3000 & 3 & 108.5326 & 2.54034 \\
& Total & 187 & 99.3168 & 11.87934 \\
Struggle against Obstacles & 1000 & 30 & 88.7326 & 12.969 \\
& $1001-2000$ & 154 & 84.5724 & 20.8461 \\
& 3000 & 3 & 46.4442 & 4.2339 \\
& Total & 187 & 84.6274 & 20.25122 \\
& 1000 & 30 & 96.1312 & 3.34906 \\
Total & $1001-2000$ & 154 & 91.9072 & 9.6789 \\
& 3000 & 3 & 71.1018 & 0.5522 \\
& Total & 187 & 92.2504 & 9.41028 \\
\hline
\end{tabular}

Table 13. Average scores of the participants according to their disability levels

\begin{tabular}{ccccc}
\hline & & $\mathrm{N}$ & $\mathrm{X}$ & Std. D. \\
\hline \multirow{4}{*}{ Starting Behavior } & $\mathrm{B} 1$ & 61 & 91.3814 & 11.70378 \\
& $\mathrm{~B} 2$ & 74 & 88 & 13.70842 \\
& $\mathrm{~B} 3$ & 52 & 94.4526 & 6.6 \\
& Total & 187 & 90.8974 & 11.69762 \\
& $\mathrm{~B} 1$ & 61 & 90.0614 & 15.41694 \\
Maintaining Behavior & $\mathrm{B} 2$ & 74 & 89.1462 & 12.96944 \\
& $\mathrm{~B} 3$ & 52 & 98.395 & 5.2272 \\
Completion of the & Total & 187 & 92.0172 & 12.8876 \\
Behavior & $\mathrm{B} 1$ & 61 & 101.849 & 9.01142 \\
& $\mathrm{~B} 2$ & 74 & 95.7902 & 15.23412 \\
Struggle against & $\mathrm{B} 3$ & 52 & 101.3694 & 7.54402 \\
Obstacles & Total & 187 & 99.3168 & 11.87934 \\
& $\mathrm{~B} 1$ & 61 & 85.2346 & 20.9209 \\
& $\mathrm{~B} 2$ & 74 & 82.6496 & 19.8451 \\
& $\mathrm{~B} 3$ & 52 & 86.7306 & 20.16036 \\
& Total & 187 & 84.6274 & 20.25122 \\
Total & $\mathrm{B} 1$ & 61 & 92.4528 & 8.57472 \\
& $\mathrm{~B} 2$ & 74 & 89.3442 & 11.49346 \\
& $\mathrm{~B} 3$ & 52 & 96.1488 & 4.42398 \\
& Total & 187 & 92.2504 & 9.41028 \\
\hline
\end{tabular}

\section{Discussion and Result}

This study was conducted with the aim of determining self efficacy-sufficiency levels of 60 females, and 127 males, a total of 187 , visually impaired individuals.

When the findings of participants' self-sufficiency scores according to gender were analyzed, it was found that there was a significant difference in participants' scores according to gender, and males have higher self-sufficiency scores than females $(\mathrm{t}(185)=6.041, \mathrm{p}<.05)$. When the literature was reviewed, there are studies suggesting that there is a significant difference in general self-efficacy levels according to gender variable (Brink et al., 2012; Britner \& Pajares, 2006; Creed \& Patton, 2003; Scholz et al., 2002). This situation may result from the 
fact that men are given more responsibility in the society we live in, they can express themselves more in society, they stand out, they are given reassuring responsibilities, they have different mission in the community, they choose the professions where they feel they are sufficient; but females are not given such responsibilities and they are pushed into the background.

When we looked at the sub-factors of the self-sufficiency scores; it was found that there was a significant difference in favor of males according to gender in sub-factors of Starting Behavior $(\mathrm{t}(185)=5.109, \mathrm{p}<.05)$, Maintaining Behavior $(\mathrm{t}(185)=5.931, \mathrm{p}<.05)$, Completion of the Behavior $(\mathrm{t}(185)=2.490, \mathrm{p}<.05)$; but in sub-factor of Struggle against Obstacles $(\mathrm{t}(185)=1,850, \mathrm{p}>.05)$, it was found that there was no significant difference according to gender In different studies, it is seen that the general self-efficacy level is significantly different from gender. Looking at the sub-factors of self-efficacy scores; it was found that there was a significant difference according to gender in favor of men in Starting Behavior, Maintaining behavior, Completion of the Behavior. In this respect, we think that women's self-sufficiency scores being different compared to men may be resulted from the fact that women are able to show and express themselves in society. In the struggle against obstacles, there is no meaningful difference according to gender, and we think that women and men cannot struggle and accept the negative ones from outside, they are not different in the struggle against obstacles as a result of the feeling they feel adequate in society.

When the findings of participants' self-sufficiency scores according to disability status were analyzed, it was found that there was a significant difference in attitudes of participants with congenital and afterward disability according to disability status $(\mathrm{t}(185)=-2.561, \mathrm{p}<.05)$. Looking at the sub-factors of the Self-Sufficiency scores, it was found that there was significant difference in favor of individuals with afterward disability in sub-factors of Maintaining Behavior $(\mathrm{t}(185)=-2.933, \mathrm{p}<.05)$, and Completion of the Behavior $(\mathrm{t}(185)=-2.144, \mathrm{p}<.05)$; but in sub-factors of Starting Behavior $(\mathrm{t}(185)=-1.526, \mathrm{p}>.05)$ and Struggle against Obstacles $(\mathrm{t}(185)=-.302, \mathrm{p}>.05)$, it was found that there was no significant difference between individuals with congenital and afterward disability. According to Luszczynska et al. (2005), self-efficacy determines how individuals feel, think, motivate themselves and act. Visually impaired individuals often feel that it is difficult and complex to maintain a sense of appropriate sufficiency. They often have to establish a good balance between their hopes and unrealistic expectations about the future. If the self-efficacy levels of people with disabilities are high, it is easier for them to provide this balance in the face of their stressful life situations (Özkan \& Ak1, 2016). It would be more difficult for them to maintain this balance if it is low. When the self-efficacy levels of the visually impaired, both congenital and afterward, are examined, it can be said that they are individuals who can use their own self-efficacy in a different way. We think that the type of disability is effective on self-sufficiency and there is a difference between individuals' having congenital or afterward disability and their self-sufficiency levels. Since there are no similar studies in our study, there are no findings to support.

When the findings of participants' self-sufficiency scores according to branches of sports were analyzed, it was found that there was no significant difference in individual and team sports doing participants scores according to branches of sports $(\mathrm{t}(185)=-.846, \mathrm{p}>.05)$. When looked at sub-factors of the self-sufficiency scores, there was no significant difference according to branches of sports in sub-factors of Starting Behavior $(\mathrm{t}(185)=1.405, \mathrm{p}>.05)$, Maintaining Behavior $(\mathrm{t}(185)=-.171, \mathrm{p}>.05)$, and Completion of the Behavior $(\mathrm{t}(185)=-1.972, \mathrm{p}>.05)$; but in sub-factors of Struggle against Obstacles $(\mathrm{t}(185)=-3.074, \mathrm{p}<.05)$, there was a significant difference in favor of team sports doers. In the study conducted by Şanlı (2014) on the general self-efficacy of the police academy students, he reported that the sports branch did not affect the general self-sufficiency level. We can say that Self-sufficiency opens wider paths in sports field and sport is a skill, and self-efficacy of individuals with good skill is also high. We think that Self-sufficiency has a positive relationship with the team and individual sports, if individuals can control their feeling, this situation will increase performance in sports in a positive way, and it is resulted from that there is significant difference between self-sufficiency, individual and team sports. Since similar studies were conducted, the finding that supports this idea in our study has been reached.

When one-way ANOVA results of the participants' Self-Sufficiency scores were analyzed according to age groups, it was stated that there was a significant difference in self-sufficiency scores of the participants according to age groups $(\mathrm{F}(2,184)=8.348, \mathrm{p}<.05)$. When literature is viewed, it is seen that self-sufficiency level is differentiated according to age (Aypay, 2010; Creed \& Patton, 2003; Scholz et al., 2002). Again when sub-factors were analyzed according to age groups, it was stated that there was differentiation in sub-factors of Starting Behavior $(\mathrm{F}(2,184)$ $=10.209, \mathrm{p}<.05)$, Maintaining Behavior $(\mathrm{F}(2,184)=9.025, \mathrm{p}<.05)$, and Struggle against Obstacles $(\mathrm{F}(2,184)$ $=6.330, \mathrm{p}<.05)$; but in sub-factors of Completion of the Behavior $(2,184)=2.435, \mathrm{p}>.05)$, it was found that there was no difference according to age groups. In other words, the individual's age, self-sufficiency, and sub-groups are very important in terms of starting behavior, maintaining behavior, and struggle against obstacles. 
However, it is thought that the age of the individual is not important in the completion of the behavior. As a result of Post Hoc tests to determine in which of these three sub-factors the differentiation occurred; it was seen that there was difference between under 18 years and 18-30 years, and under 18 years and over 30 years in Starting Behavior; between under 18 years and 18-30 years in Maintaining Behavior; between under 18 years and over 30 years, and 18-30 years and over 30 years in Struggle against Obstacles. In general of self-sufficiency scores, it was stated that there was a difference between under 18 years and 18-30 years, and under 18 years and over 30 years. Besides when the literature is viewed, not many studies analyzing sub-scale of athletes' self-sufficiency according to age group were found. It can be said that it is related to the life experience of athletes from different age groups.

When one-way ANOVA results related to Self-Sufficiency scores according to education status were examined, it was found that there was a differentiation in self-sufficiency scores of the participants according to education status $(\mathrm{F}(2,184)=14.655, \mathrm{p}<.05)$. When sub-factor were analyzed according to education status, it was found that there was difference according to education status in sub-factors of Starting Behavior $(2,184)=12.145, \mathrm{p}$ $<.05)$, Maintaining Behavior $(\mathrm{F}(2,184)=7.118, \mathrm{p}<.05)$, and Struggle against Obstacles $(\mathrm{F}(2,184)=15.336, \mathrm{p}$ $<.05)$; but in sub-factors of Completion of the Behavior $(\mathrm{F}(2,184)=1.349, \mathrm{p}>.05))$, it was found that there was no difference. As a result of Post Hoc tests to determine in which of these three sub-factors the differentiation occurred; there was a difference among all groups in Starting Behavior scores; between primary school and high school graduates, and high school and university graduates in Maintaining Behavior scores; between primary school and university graduates, and high school and university graduates in Struggle against Obstacles scores. In general average, it was found that there was a significant difference among all groups. In their study, Özkan and Ak1 (2016) found that there is a significant difference between self-sufficiencies of low vision and visually impaired individuals according to their educational status. Yiğitbaş and Yetkin (2003), and Zengin's (2007) findings show similarity that examined the self-efficacy and sufficiency levels of health high school students. In their study, Sevindik et al. (2007) found that the total and the sub-group mean scores of the 4th-grade students are higher than the first-grade students. Tiler (1995) in his study of the class progression has been determined that the average score of SESS points. The problem-based learning (PBL) model, which aims to provide students with self-managed learning, independent study, questioning, and problem-solving skills, is a method in which people are faced with conditions that may be considered as an analogy to the situations they will face in their lives and they are guided to solve these situations by self-research and learning (Turan \& Demirel, 2010). We can say that the level of self-efficacy is different due to the fact that the visually impaired individuals have the qualifications to support or improve their self-efficacy levels as the level of education they receive an increase. These features are the values that the individual have gained in the process of education, knowledge, skills, and habits, thinking, admiration (Demirova, 2008). In fact, education is the most prominent tool for developing societies (Yaşar, 2017).

When one-way ANOVA results related to Self-Sufficiency scores according to the level of income were examined, it was found that there was a significant differentiation in self-sufficiency scores of the participants according to the level of income $(\mathrm{F}(2,184)=11.370, \mathrm{p}<.05)$. When sub-factors were analyzed according to level of income; it was found that there was difference in sub-factors of Starting Behavior $(2,184)=17.026, p<.05)$, Maintaining Behavior $(\mathrm{F}(2,184)=6.217, \mathrm{p}<.05)$, and Struggle against Obstacles $(\mathrm{F}(2,184)=6.288, \mathrm{p}<.05)$; but in sub-factor of Completion of the Behavior $(\mathrm{F}(2,184)=2.380, \mathrm{p}>.05)$, it was found that there was no differentiation. As a result of Post-Hoc tests to determine in which of these three sub-factors the differentiation occurred; it was stated that there was a difference between 1000 and 3000, and 1000-2000 and 3000 in general average of the self-sufficiency. It was stated that there was a significant difference between 1000 and 3000, 1000-2000 and 3000 in Starting Behavior scores; between 1000 and 3000, 1000-2000 and 3000 in Maintaining Behavior; between 1000 and 3000, and 1000-2000 and 3000 in Struggle against Obstacles in sub-factors. In a study on the self-sufficiency levels of the individuals with low vision and visually impaired individuals, Özkan and Ak1 (2016) found that self-sufficiency levels were different in favor of the visually impaired individuals in terms of the level of income. Self-efficacy is defined as being aware of and a belief in their ability to do a job. Bandura (2000) stated that self-sufficiency belief plays a vital role in the success of the individual under different conditions. As it can be understood from the definition, as well as an individual's being successful in a job as a result of the ability of a person to do a job is firstly about his level of income being decent and feeling relaxed; the level of income may be effective on self-sufficiency.

When one-way ANOVA results related to Self-Sufficiency scores according to visual acuity were examined, it was found that there was a differentiation in self-sufficiency scores of the participants according to visual acuity ( $\mathrm{F}(2$, $184)=8.665, \mathrm{p}<.05)$. When sub-factors were analyzed according to visual acuity; it was found that there was difference in sub-factors of Starting Behavior $(2,184)=4.922, \mathrm{p}<.05)$, Maintaining Behavior $(\mathrm{F}(2,184)=9.745$, $\mathrm{p}<.05)$, and Completion of the Behavior $(\mathrm{F}(2,184)=5.699, \mathrm{p}<.05)$; but in sub-factors of Struggle against 
Obstacles $(F(2,184)=.659, p>.05))$, no significant difference was found. As a result of Post Hoc tests to determine in which of these three sub-factors the differentiation occurred; it was stated that there was a difference between B2 and B3 in Starting Behavior score; between B1 and B3, and B2 and B3 in Maintaining Behavior; between $\mathrm{B} 1$ and $\mathrm{B} 2$, and $\mathrm{B} 2$ and $\mathrm{B} 3$ in Completion of the Behavior. In general average of Self-Sufficiency, it was found that there was a difference between B2 and B3; but there was no differentiation in other visual acuity levels. In their study, Özkan and Akı (2016) found that there was a significant difference between individuals with low visual acuity and visually impaired ones in terms of their self-sufficiency levels. In the study performed with individuals over the age of 55 with hearing disability and chronic disease, it was determined that individuals with the hearing disability had lower self-sufficiency than those with normal hearing (Kramer et al., 2002). In another study on hearing impaired adult individuals, it was found that hearing impaired individuals had lower self-sufficiency for health behaviors than their hearing peers (Jones et al. 2007). In the study of individuals with physical disabilities with chronic pain, Rudy et al. (2003) found that the self-sufficiency level of individuals was highly correlated with their performances. In addition, regardless of the visual acuity level; considering that self-sufficiency may be affected by this obstacle, it is thought that support to increase the self-efficacy of individuals with different vision levels is important. Self efficacy-sufficiency has an effect on the degree of visual acuity; we think that the difference between self-efficacy sufficiency levels was derived from this. As there are similar studies, findings to support our study were found.

There are a certain number of people in the world and in our country who have a visual impairment. It directly affects the life of the individual. This reduces the self-sufficiency level of the individual as a result of affecting the performance of the people. For this reason, it is very important to develop the self-sufficiency of the visually impaired and other individuals with disabilities when they are required to accept the disability and to accept the disabled children in their families and to be accepted by the society. Visually impaired athletes are considered to have high self-sufficiency levels as they trust themselves through sports, prove themselves to handle, and accepted by the society, represent their country in the Paralympic, do any job, and accept his disability.

According to the results of the research; since sports is effective on visually impaired individuals, it is very important to develop strategies to intervene in sports and education for all individuals with disabilities and to improve the self-sufficiency of individuals.

\section{References}

Akı, E., \& Kayıhan, H. (2004). Az gören çocuklarda görsel algılama eğitiminin yazma, okuma ve günlük yaşam aktivitelerine etkisi.[Relationship between visual perception training and reading speed on visually impaired children]. Fizyoterapi ve Rehabilitasyon, 14(3), 95-100. https://doi.org/10.1016/s1090-3798(08)70239-3

Akkoyunlu, B., \& Orhan, F. (2003). Bilgisayar ve öğretim teknolojileri eğitimi (BÖTE) bölümü öğrencilerinin bilgisayar kullanma öz yeterlik inanc1 ile demografik özellikleri arasındaki ilişki. The Turkish Online Journal of Educational Technology, 2(3), 86-93. Retrieved from http://www.tojet.net/articles/v2i3/2311.pdf

Aypay, A. (2010). Genel Öz Yeterlik Ölçeği'nin (GÖYÖ) Türkçe’ye Uyarlama Çalışması.[The Adaptation Study of General Self-Efficacy (GSE) Scale to Turkish]. Inönü Üniversitesi Eğitim Fakültesi Dergisi, 11(2), 113-131. Retrieved from https://toad.halileksi.net/sites/default/files/pdf/genel-oz-yeterlik-olcegi-toad.pdf

Bandura, A. (1986). Social foundations of thought and action. Englewood Cliffs, NJ.

Bandura, A. (1994). Self-efficacy. In V. S. Ramachaudran (Ed.), Encyclopedia of human behavior (Vol. 4. pp. 71-81). New York: Academic Press. Retrieved from http://www.uky.edu/ eushe2/Pajares/self-efficacy

Bandura, A. (1997). Self-Efficacy in changing societies. In A. Bandura (Ed.), Exercise of personal and collective efficacy in changing societies. New York: Cambridge University Press.

Bandura, A. (2000). Cultivate self-efficacy for personal and organizational effectiveness. Handbook of principles of organization behavior, 2, 11-21.

Bray, S. R. (2004). Collective efficacy, group goals, and group performance of a muscular endurance task. Small Group Research, 35(2), 230-238. https://doi.org/10.1177/1046496403260531

Brink, E., Alsén, P., Herlitz, J., Kjellgren, K., \& Cliffordson, C. (2012). General self-efficacy and health-related quality of life after myocardial infarction. Psychology, Health \& Medicine, 17(3), 346-355. https://doi.org/10.1080/13548506.2011.608807

Britner, S. L., \& Pajares, F. (2006). Sources of science self-efficacy beliefs of middle school students. Journal of Research in Science Teaching: The Official Journal of the National Association for Research in Science Teaching, 43(5), 485-499. https://doi.org/10.1002/tea.20131 
Cengiz, R., Korucu-Aytan, G., \& Abakay, U. (2012). Taekwondo Sporcularının Algıladığı Liderlik Özellikleri İle Öz-Yeterlik Düzeyleri Arasındaki İlişki [The Relatıonshıp Between Self-Effıcacy Levels and Leadershıp Qualities That The Taekwondo Athlete Perceive]. E-Journal of New World Sciences Academy, 7(4), 69-78. Retrieved from http://www.newwsa.com

Chase, M. A. (1998). Sources of self-efficacy in physical education and sport. Journal of Teaching in Physical Education, 18(1), 76-89. https://doi.org/10.1123/jtpe.18.1.76

Creed, P. A., \& Patton, W. (2003). Predicting two components of career maturity in school based adolescents. Journal of career Development, 29(4), 277-290. https://doi.org/10.1177/089484530302900405

Demirova, G. (2008). Piyano Ĕ̆itiminin İlköğretim Öğrencilerinin Dikkat Toplama Yetisine Etkisi. Doktora Tezi, Ankara Üniversitesi Eğitim Bilimleri Enstitüsü. Retrieved from http://acikarsiv.ankara.edu.tr/browse/4389/

Eysenck, H. J. (1982). The biological basis of cross-cultural differences in personality: Blood group antigens. Psychological Reports, 51(2), 531-540. https://doi.org/10.2466/pr0.1982.51.2.531

George, D., \& Mallery, P. (1999). SPSS ${ }^{\circledR}$ for Windows ${ }^{\circledR}$ step by step: A simple guide and reference. Allyn \& Bacon. Retrieved from https://psycnet.apa.org/record/1998-07683-000

Gibson, C. B. (1999). Do they do what they believe they can? Group efficacy and group effectiveness across tasks and cultures. Academy of Management Journal, 42(2), 138-152. https://doi.org/10.5465/257089

Gibson, C. B., Randel, A. E., \& Earley, P. C. (2000). Understanding group efficacy: An empirical test of multiple assessment methods. Group \& organization management, 25 (1), 67-97. https://doi.org/10.1177/1059601100251005

Gözüm, S., \&Aksayan, S. (1999). Öz-Etkililik-Yeterlik Ölçeğinin Türkçe Formunun Güvenirlilik ve Geçerliliği. Atatürk Üniversitesi Hemşirelik Yüksekokulu Dergisi, 2(1), 21-34. Retrieved from https://toad.halileksi.net/olcek/oz-etkililik-yeterlik-olcegi

Guzzo, R. A., Yost, P. R., Campbell, R. J., \& Shea, G. P. (1993). Potency in groups: Articulating a construct. British journal of social psychology, 32(1), 87-106. https://doi.org/10.1111/j.2044-8309.1993.tb00987.x

Jones, E. G., Renger, R., \& Kang, Y. (2007). Self-efficacy for health-related behaviors among deaf adults. Research in nursing \& health, 30(2), 185-192. https://doi.org/10.1002/nur.20196

Kayri, M. (2009). Araştırmalarda Gruplar Arası Farkın Belirlenmesine Yönelik Çoklu Karşılaştırma (Post-Hoc) Teknikleri. Firat Üniversitesi Sosyal Bilimler Dergisi, Firat University Journal of Social Science, 19(1), 51-64. Retrieved from http://web.firat.edu.tr/sosyalbil/dergi/arsiv/cilt19/sayi1/051-064.pdf

Kramer, S. E., Kapteyn, T. S., Kuik, D. J., \& Deeg, D. J. (2002). The association of hearing impairment and chronic diseases with psychosocial health status in older age. Journal of aging and health, 14(1), 122-137. https://doi.org/10.1177/089826430201400107

Luszczynska, A., Gutiérrez-Doña, B., \& Schwarzer, R. (2005). General self-efficacy in various domains of human functioning: Evidence from five countries. International journal of Psychology, 40(2), 80-89. https://doi.org/10.1080/00207590444000041

Myers, N. D., Feltz, D. L., \& Short, S. E. (2004). Collective Efficacy and Team Performance: A Longitudinal Study of Collegiate Football Teams. Group Dynamics: Theory, Research, and Practice, 8(2), 126. https://doi.org/10.1037/1089-2699.8.2.126

Özkan. E., \& Akı. E. (2016). Az Gören ve Görme Engelli Bireylerin Öz Yeterlilikleri ve Baş Etme Becerileri Arasındaki İlişki. Ergoterapi ve Rehabilitasyon Dergisi, 4(2), 81-88. Retrieved from https://dergipark.org.tr/download/article-file/388720

Rudy, T. E., Lieber, S. J., Boston, J. R., Gourley, L. M., \& Baysal, E. (2003). Psychosocial predictors of physical performance in disabled individuals with chronic pain. The Clinical journal of pain, 19(1), 18-30. https://doi.org/10.1097/00002508-200301000-00003

Sbea, G. P., \& Guzzo, R. A. (1987). Group effectiveness: What really matters? Sloan Management Review (1986-1998), 28(3), 25.

Scholz, U., Doña, B. G., Sud, S., \& Schwarzer, R. (2002). Is general self-efficacy a universal construct? Psychometric findings from 25 countries. European journal of psychological assessment, 18(3), 242. https://doi.org/10.1027//1015-5759.18.3.242

Schwarzer, R., \& Fuchs, R. (1995). Self-Efficacy and Health Behaviour, to appear in Conner M. Norman, P. 
Predicting Health Behaviour: Research and Practice with Social Cognition Models.

Sevindik, T., Yeşil, G., Sevindik, F., \& Açık, Y. (2007). Üniversite Öğrencilerinde Benlik Saygısı İle Öz-Etkililik Yeterlik Arasındaki İlişki. e-Journal of New World Sciences Academy, 2(2), 13-22. Retrieved from http://www.newwsa.com

Sherer, M., Maddux, J. E., Mercandante, B., Prentice-Dunn, S., Jacobs, B., \& Rogers, R. W. (1982). The self-efficacy scale: Construction and validation. Psychological reports, 51(2), 663-671. https://doi.org/10.2466/pr0.1982.51.2.663

Şanlı, S. (2014). Polis Akademisi Öğrencilerinin Genel Öz Yeterlik İnançları ve Sporda Güdülenme Kaynaklarının İncelenmesi. Hacettepe Spor Bilimleri Dergisi, 25(4), 172-183. Retrieved from http://www.sbd.hacettepe.edu.tr/fulltext/2014_4_2.pdf

Tiler, D. (1995). Self-efficacy in college students. Retrieved from http://www.mwsc.edu/psychology/research/psy302/fall95/tiller.html.

Turan, S., \& Demirel, Ö. (2010). The Reliability and Validity of the Attitude Scale Towards Problem Based Learning. Eğitim ve Bilim, 34(152). Retrieved from https://pdfs.semanticscholar.org

Turkey Disability Survey. (2002). Retrieved from https://kutuphane.tuik.gov.tr/pdf/0014899.pdf

Türedi, E. (2015). Öz-yeterlik, Benlik Saygısı ve Atılganlık Düzeyi Illişkisi-Cinsiyet ve Deneyim Süresi Açısından Resmi Okul ve Özel Okul Ögretmenleri Üzerine Bir Araştırma. Psikoloji Yüksek Lisans Tezi, T.C. Toros Üniversitesi Sosyal Bilimler Enstitüsü.

Üstüner, M., Demirtaş, H., Cömer, M., \& Özer, N. (2009). Ortaöğretim Öğretmenlerinin Öz-Yeterlik Algıları. Mehmet Akif Ersoy Üniversitesi Ĕgitim Fakültesi Dergisi, 9(17), 1-16. Retrieved from https://www.researchgate.net/publication/285376012_Ortaogretim_ogretmenlerinin_oz-yeterlik_algilari

WHO. (2013). Visual impairment and blindness. Erişim tarihi: 11 Aralık 2018. Retrieved from https://www.who.int/news-room/fact-sheets/detail/blindness-and-visual-impairment

Yaşar, Ö. (2017). Eğitimsizlik Sarmalının Kısır Döngüsündeki: Roman Çocukların Eğitimi. Journal Of Socıal and Humanittes Sciences Research, 4(12), 1241-1253. https://doi.org/10.26450/jshsr.208

Yılmaz, M., Gürçay, D., \& Ekici, G. (2007). Akademik özyeterlik ölçeğinin Türkçe’ye uyarlanması. Hacettepe Üniversitesi Eğitim Fakültesi Dergisi, 33(33), 253-259. Retrieved from https://toad.halileksi.net/olcek/akademik-ozyeterlik-olcegi

Yiğitbaş, Ç., \& Yetkin, A. (2003). Sağlık yüksekokulu öğrencilerinin özetkililik-yeterlik düzeyinin

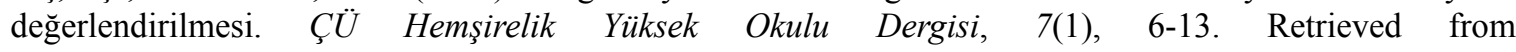
http://eskidergi.cumhuriyet.edu.tr/makale/617.pdf

Zengin, N. (2007). Sağlık Yüksekokulu Öğrencilerinde Öz-Etkililik-Yeterlilik Algısı ve Klinik Uygulamada Yaşanılan Stresle İlişkisinin İncelenmesi. Anadolu Hemşirelik ve Sağlık Bilimleri Dergisi, 10(1), 49-57. Retrieved from https://dergipark.org.tr/ataunihem/issue/2636/33912

\section{Copyrights}

Copyright for this article is retained by the author(s), with first publication rights granted to the journal.

This is an open-access article distributed under the terms and conditions of the Creative Commons Attribution license (http://creativecommons.org/licenses/by/4.0/). 